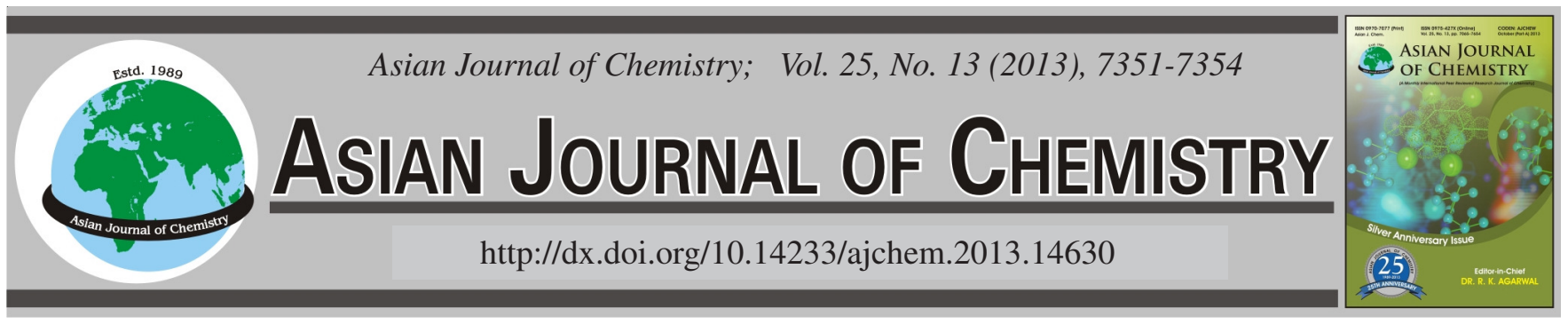

\title{
Highly Efficient, Selective and Ultrasound-Assisted Monohydrolysis of Polyhedral Diesters in Co-solvent
}

\author{
H.L. Zhang, X.H. ZhU, H. YAN" and X.Q. Song
}

College of Life Science and Bio-Engineering, Beijing University of Technology, Pingleyuan Street No. 100, Chaoyang District, Beijing 100124, P.R. China

*Corresponding author: Fax: +86 10 67396642; Tel: +86 10 67396211; E-mail: hongyan@ bjut.edu.cn

(Received: 29 September 2012;

Accepted: 28 June 2013)

AJC-13706

\begin{abstract}
In this work, a new procedure for the selective monohydrolysis of polyhedral diesters is reported. The optimal conditions with regard to the catalytic activity, quantity of catalyst, ultrasound irradiation power, solvents and both the reaction and separation temperatures were examined. A series of polyhedral monoesters were obtained in high yield using 1-2 mol \% of $p$-toluene sulphonic acid in a co-solvent under ultrasonic irradiation. This work not only leads to a practical synthetic method for polyhedral monoesters, but also provides a new approach to acid-catalyzed selective monohydrolysis.

Key Words: Polyhedral diesters, Monoesters, $p$-Toluene sulphonic acid, Co-solvents, Acid-catalyzed monohydrolysis.
\end{abstract}

\section{INTRODUCTION}

Monoesters, which are produced through the selective monohydrolysis of diesters, are versatile building blocks in organic synthesis. However, few efficient methods to selectively hydrolyze one of the ester groups have been reported. The classic alkaline hydrolysis does not usually afford easily manageable results and gives complicated slurry mixtures of both the di- and monocarboxylic acids as well as the starting diester. Only a few examples of selective hydrolysis catalyzed by enzymes or bases such as $\mathrm{NaOH}$ in co-solvents have been reported ${ }^{1-5}$.

The fascination with polyhedron chemistry, including adamantane, cubane, homocubane and asterane, has continued unabated because of their unique structure, high tensile energy and, in particular, their potential as antitumor and antiviral agents $^{6,7}$. Symmetric polyhedral diesters are inexpensive and easily prepared and routine access to polyhedral monoesters which is important for the synthesis of polyhedron derivatives. Della and Tsanaktsidis ${ }^{8}$ monohydrolyzed dimethyl 1,4cubanedicarboxylate using $\mathrm{Ba}(\mathrm{OH})_{2}$ as catalyst in $36 \%$ yield. Moriarty et $a l .{ }^{9}$ improved this procedure by using $\mathrm{NaOH}$ as the catalyst and THF as a co-solvent to obtain a yield up to $95 \%$. However, using the above methods to hydrolyze dimethyl 2,4-homocubane dicarboxylate yields complex mixtures of the starting diester, monoesters and diacids even when using only one equivalent of the base, which makes separation and purification difficult. In contrast, the complicated and rigid molecular structure of homocubane makes ringopening reactions in basic solution rather common. Therefore, it is necessary to develop an efficient method to selectively monohydrolyze these polyhedral diesters.

Ester hydrolysis can also be catalyzed by acids. However, no selective, acid-catalyzed monohydrolysis of symmetric diesters has been reported ${ }^{10-13}$. Based on the different solubilities of the diesters and their relative monoesters in nonpolar solvents, once one of the ester groups has been selectively hydrolyzed, the resulting monoesters will be deposited in the nonpolar solvent, thus prohibiting further hydrolysis. Cosolvents are considered to be of great importance in the monohydrolysis of polyhedral diesters and their effects on the solubility of the catalyst in nonpolar solvents are the subject of this work. Moreover, ultrasonic irradiation has been widely applied to various types of organic reactions to achieve higher yields and shorter reaction times using milder conditions through the formation and adiabatic collapse of transient cavitation bubbles ${ }^{14-16}$. We report a method to synthesize polyhedral monoesters using an acid catalyst in a co-solvent, promoted by ultrasound irradiation (Scheme-I).

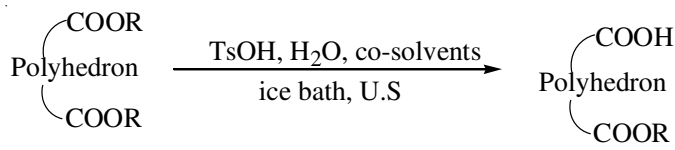

Polyhedron = 1: Adamantane, 2: Cubane , 3: Homocubane $\mathrm{R}=\mathrm{a}: \mathrm{CH}_{3}$; b: $\mathrm{CH}_{2} \mathrm{CH}_{3}$; $:$ n- $\mathrm{CH}_{2} \mathrm{CH}_{2} \mathrm{CH}_{3}$

Scheme-I: Monohydrolysis of polyhedral diesters 


\section{EXPERIMENTAL}

All melting points are uncorrected. ${ }^{1} \mathrm{H}$ NMR at $400 \mathrm{MHz}$ and ${ }^{13} \mathrm{C} \mathrm{NMR}$ at $100 \mathrm{MHz}$ spectra were measured in $\mathrm{CDCl}_{3}$ solutions using TMS as an internal standard. HRMS spectra were recorded on an Agilent 6210 high-resolution mass spectrometer.

General procedure: The diester $(10 \mathrm{mmol})$ was dissolved in $50 \mathrm{~mL}$ of hexane and a solution of $p$ - $\mathrm{TsOH}(0.15 \mathrm{mmol}$ in $5 \mathrm{~mL}$ of toluene) was added. The reaction mixture was immersed in an ice-water bath and cooled to $0^{\circ} \mathrm{C}$ and $11 \mathrm{mmol}$ $(0.2 \mathrm{~mL})$ of $\mathrm{H}_{2} \mathrm{O}$ was added under ultrasonic irradiation until the initial consumption of the starting diester was observed by thin-layer chromatography. The reaction proceeded at the same temperature and the reaction mixture was cooled to $-20^{\circ} \mathrm{C}$ for purification. A fine white precipitate formed and was carefully filtered. The precipitate was washed with hexane and dried under high vacuum to yield a stable white powder.

Monoester (1a): White solid, m.p. $257-258^{\circ} \mathrm{C} ;{ }^{1} \mathrm{H}$ NMR $\left(400 \mathrm{MHz}, \mathrm{CDCl}_{3}\right) \delta: 1.71(\mathrm{~s}, 2 \mathrm{H}), 1.82-1.92(\mathrm{~m}, 8 \mathrm{H}), 2.07(\mathrm{~s}$, $2 \mathrm{H}), 2.20(\mathrm{~s}, 2 \mathrm{H}), 3.40(\mathrm{~s}, 3 \mathrm{H}), 11.63(\mathrm{~s}, 1 \mathrm{H})$. The spectroscopic data matched that reported in the literature ${ }^{17}$.

Monoester (1b): White solid, m.p. 269-270 ${ }^{\circ} \mathrm{C} ;{ }^{1} \mathrm{H}$ NMR (400 MHz, $\left.\mathrm{CDCl}_{3}\right) \delta: 1.24(\mathrm{t}, J=14 \mathrm{~Hz}, 3 \mathrm{H}), 1.69(\mathrm{~s}, 2 \mathrm{H})$, 1.83-1.92 (m, 8H), 2.05 (s, 2H), 2.17 (s, 2H), 4.12 (q, $J=22$ $\mathrm{Hz}, 2 \mathrm{H}), 11.66(\mathrm{~s}, 1 \mathrm{H}) .{ }^{13} \mathrm{C} \mathrm{NMR}\left(100 \mathrm{MHz}, \mathrm{CDCl}_{3}\right) \delta: 14.2$, 27.8, 35.3, 37.7, 37.9, 39.5, 40.7, 40.8, 60.3, 167.8, 176.7, 183.3. HRMS calcd. (\%) for $\mathrm{C}_{14} \mathrm{H}_{20} \mathrm{O}_{4} 252.1362$, found (\%) 252.1359 .

Monoester (1c): White solid, m.p. $281-282{ }^{\circ} \mathrm{C} ;{ }^{1} \mathrm{H}$ NMR $\left(400 \mathrm{MHz}, \mathrm{CDCl}_{3}\right) \delta: 0.94(\mathrm{t}, J=15 \mathrm{~Hz}, 3 \mathrm{H}), 1.62-1.69(\mathrm{~m}$, $4 \mathrm{H}), 1.83-1.89(\mathrm{~m}, 8 \mathrm{H}), 2.05(\mathrm{~s}, 2 \mathrm{H}), 2.17(\mathrm{~s}, 2 \mathrm{H}), 4.03(\mathrm{t}, J=$ $13 \mathrm{~Hz}, 2 \mathrm{H}), 11.78$ (s, $1 \mathrm{H}) .{ }^{13} \mathrm{C} \mathrm{NMR}\left(100 \mathrm{MHz}, \mathrm{CDCl}_{3}\right) \delta$ : 10.4, 22.0, 27.8, 35.3, 37.7, 37.9, 39.5, 41.8, 42.9, 65.9, 176.7, 183.2. HRMS calcd. (\%) for $\mathrm{C}_{15} \mathrm{H}_{22} \mathrm{O}_{4} 266.1518$, found (\%) 266.1513.

Monoester (2a): White solid, m.p. $182-183{ }^{\circ} \mathrm{C} ;{ }^{1} \mathrm{H}$ NMR

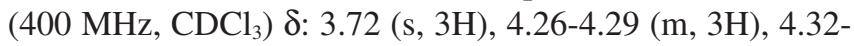
$4.34(\mathrm{~m}, 3 \mathrm{H}), 11.64(\mathrm{~s}, 1 \mathrm{H})$. The spectroscopic data matched that reported in the literature ${ }^{18}$.

Monoester (2b): White solid, m.p. 302-303 ${ }^{\circ} \mathrm{C} ;{ }^{1} \mathrm{H}$ NMR $\left(400 \mathrm{MHz}, \mathrm{CDCl}_{3}\right) \delta: 1.31(\mathrm{t}, J=14 \mathrm{~Hz}, 3 \mathrm{H}), 4.20$ (q, $J=21$ $\mathrm{Hz}, 2 \mathrm{H}), 4.26-4.31$ (m, 3H), 4.32-4.35(m, 3H), 11.67(s, 1H); ${ }^{13} \mathrm{C} \mathrm{NMR}\left(100 \mathrm{MHz}, \mathrm{CDCl}_{3}\right) \delta: 14.3,41.7,46.9,47.1,55.9$, $60.8,171.5,183.3$. HRMS calcd for $\mathrm{C}_{12} \mathrm{H}_{12} \mathrm{O}_{4} 202.0736$, found (\%) 202.0735 .

Monoester (2c): White solid, m.p. $314-315^{\circ} \mathrm{C} ;{ }^{1} \mathrm{H}$ NMR $\left(400 \mathrm{MHz}, \mathrm{CDCl}_{3}\right) \delta$ : $1.12(\mathrm{t}, J=14 \mathrm{~Hz}, 3 \mathrm{H}), 1.66-1.70(\mathrm{~m}$, $2 \mathrm{H}), 4.08(\mathrm{t}, J=14 \mathrm{~Hz}, 2 \mathrm{H}), 4.25-4.27(\mathrm{~m}, 3 \mathrm{H}), 4.32-4.35(\mathrm{~m}$, $3 \mathrm{H}), 11.58(\mathrm{~s}, 1 \mathrm{H}),{ }^{13} \mathrm{C} \mathrm{NMR}\left(100 \mathrm{MHz}, \mathrm{CDCl}_{3}\right) \delta: 10.2,22.1$, 41.6, 46.9, 55.9, 47.2, 66.0, 171.5, 183.2. HRMS calcd. (\%) for $\mathrm{C}_{13} \mathrm{H}_{14} \mathrm{O}_{4} 234.0892$, found (\%) 234.0890.

Monoester (3a): White solid, m.p. 299-300 ${ }^{\circ} \mathrm{C} ;{ }^{1} \mathrm{H}$ NMR $\left(400 \mathrm{MHz}, \mathrm{CDCl}_{3}\right) \delta: 1.68(\mathrm{~d}, J=30 \mathrm{~Hz}, 2 \mathrm{H}), 3.24-3.48(\mathrm{~m}$, $6 \mathrm{H}), 3.54$ (s, 3H), 11.72 (s, 1H), ${ }^{13} \mathrm{C} \mathrm{NMR}\left(100 \mathrm{MHz}, \mathrm{CDCl}_{3}\right)$ $\delta: 30.2,33.1,36.5,41.5,42.7,43.9,48.9,49.1,51.6,57.7$, 172.2, 185.9. HRMS calcd. (\%) for $\mathrm{C}_{12} \mathrm{H}_{12} \mathrm{O}_{4} 220.0736$, found (\%) 220.0732 .
Monoester (3b): White solid, m.p. $310-311{ }^{\circ} \mathrm{C}$; ${ }^{1} \mathrm{H}$ NMR $\left(400 \mathrm{MHz}, \mathrm{CDCl}_{3}\right) \delta: 1.25(\mathrm{t}, J=14 \mathrm{~Hz}, 3 \mathrm{H}), 1.88(\mathrm{~d}, J=31$ $\mathrm{Hz}, 2 \mathrm{H}), 3.34-3.51(\mathrm{~m}, 6 \mathrm{H}), 3.62(\mathrm{q}, J=20 \mathrm{~Hz}, 2 \mathrm{H}), 11.73$ (s, $1 \mathrm{H}) ;{ }^{13} \mathrm{C}$ NMR $\left(100 \mathrm{MHz}, \mathrm{CDCl}_{3}\right) \delta: 14.2,29.3,33.4,36.8$, 42.1, 42.7, 43.8, 45.0, 48.8, 51.6, 58.2, 172.1, 185.3. HRMS calcd. (\%) for $\mathrm{C}_{13} \mathrm{H}_{14} \mathrm{O}_{4} 234.0892$, found (\%) 234.0887 .

Monoester (3c): White solid, m.p. $322-323{ }^{\circ} \mathrm{C}$; ${ }^{1} \mathrm{H}$ NMR $\left(400 \mathrm{MHz}, \mathrm{CDCl}_{3}\right) \delta: 0.93(\mathrm{t}, J=14 \mathrm{~Hz}, 3 \mathrm{H}), 1.67(\mathrm{~d}, J=30$ $\mathrm{Hz}, 2 \mathrm{H}), 1.84-1.91(\mathrm{~m}, 2 \mathrm{H}), 3.45-3.56$ (m, 6H), 3.93(t, $J=13$ $\mathrm{Hz}, 2 \mathrm{H}), 11.75(\mathrm{~s}, 1 \mathrm{H}) ;{ }^{13} \mathrm{C}$ NMR $\left(100 \mathrm{MHz}, \mathrm{CDCl}_{3}\right) \delta: 10.3$, 22.0, 30.4, 32.8, 34.3, 42.0, 43.4, 44.7, 48.2, 48.5, 50.6, 60.2, 171.3, 186.1. HRMS calcd. (\%) for $\mathrm{C}_{14} \mathrm{H}_{16} \mathrm{O}_{4} 248.1049$, found (\%) 248.1045 .

\section{RESULTS AND DISCUSSION}

In order to optimize the reaction conditions for the monohydrolysis of polyhedral diesters the following parameters were investigated i.e., catalytic activity, catalyst quantity, ultrasound irradiation power, solvents and reaction temperature.

The catalytic activity of $p$-dodecylbenzene sulphonic acid (DBSA), trifluoromethanesulphonic acid (TfOH), $\mathrm{H}_{2} \mathrm{SO}_{4}, \mathrm{HCl}$ and $p$-toluene sulphonic acid ( $p$-TsOH) were studied first (Table-1). The monohydrolyzation of dimethyl 1,3-adamantane dicarboxylate was performed in the absence of a catalyst using $\mathrm{H}_{2} \mathrm{O}(0.2 \mathrm{~mL})$, toluene $(5 \mathrm{~mL})$ and hexane $(50 \mathrm{~mL})$ as the solvent mixture for $10 \mathrm{~h}$ in an ice bath as a control reaction and no hydrolysis was observed (entry 1). DBSA, TfOH, $\mathrm{H}_{2} \mathrm{SO}_{4}$ and $\mathrm{HCl}$ were all inactive (entries 2-5) whereas $p$-TsOH effectively catalyzed the hydrolysis (entry 6) and gave the monoester in a yield of $76 \%$. The results may be a consequence of the water forming small droplets in the nonpolar solvent, hexane, which concentrates the catalytic species, the proton, onto the surface of the droplets where the reaction takes place. The $p$-TsOH serves as a phase transfer catalyst and transfers protons from the water into the nonpolar solvent. Because the monoester products are insoluble in the nonpolar solvent, they migrate to the aqueous phase, which pushes the equilibrium between the diesters and monoesters to the monoester side and provides the high selectivity of the monohydrolyzation. Furthermore, the white precipitate was very clean and only the monoester 1a, was observed by thin-layer chromatography; therefore, the isolation and purification were straightforward (just filtration).

The effect of the quantity of the catalyst is also shown in Table-1. It was apparent that 0.01 equivalents were insufficient to completely catalyze the hydrolysis reaction (entry 6) and 0.02 and 0.025 equivalents of $p$-TsOH did not completely dissolve in the mixed solvent system, while adding an extra $5 \mathrm{~mL}$ of toluene into the system would dissolve the resulting monocarboxylic acids and reduce the yields (entries 8-9). The best yield was obtained with 0.015 equiv. of $p-\mathrm{TsOH}$.

The effect of the quantity of $\mathrm{H}_{2} \mathrm{O}$ on the monohydrolysis of dimethyl 1,3-adamantane dicarboxylate when using $p$-TsOH as the catalyst was also investigated. The results are summarized in Table- 2 and it was apparent that $0.1 \mathrm{~mL}$ of $\mathrm{H}_{2} \mathrm{O}$ was insufficient to maximize the yield (entry 1 ), whereas 0.3 and $0.4 \mathrm{~mL}$ of $\mathrm{H}_{2} \mathrm{O}$ were found to be excessive for the monohydrolysis 


\begin{tabular}{ccccc}
\hline \multicolumn{5}{c}{ TABLE-1 } \\
\multicolumn{5}{c}{ EEFFECTS OF CATALYSTS ON THE MONOHYDROLYSIS } \\
\multicolumn{4}{c}{ OF DIMETHYL 1,3-ADAMANTANE DICARBOXYLATE } \\
\hline Entry & Catalyst & Eq. & Time (h) & ${\text { Yield }(\%)^{\mathrm{b}}}^{\mathrm{c}}$ (1) \\
\hline 1 & None & - & 10 & $0^{\mathrm{c}}$ \\
2 & $\mathrm{DBSA}$ & 0.01 & 10 & Trace $^{\mathrm{c}}$ \\
3 & $\mathrm{TfOH}$ & 0.01 & 10 & $5^{\mathrm{c}}$ \\
4 & $\mathrm{H}_{2} \mathrm{SO}$ & 0.01 & 10 & Trace $_{4}$ \\
5 & $\mathrm{HCl}$ & 0.01 & 10 & Trace $^{\mathrm{c}}$ \\
6 & $p$-TsOH & 0.01 & 2 & $76^{\mathrm{c}}$ \\
7 & $p$-TsOH & 0.015 & 2 & $88^{\mathrm{c}}$ \\
8 & $p$-TsOH & 0.02 & 2 & $70^{\mathrm{d}}$ \\
9 & $p$-TsOH & 0.025 & 2 & $63^{\mathrm{d}}$ \\
\hline
\end{tabular}

${ }^{\text {a }}$ Dimethyl 1,3-adamantanedicarboxylate $(10 \mathrm{mmol})$ in $\mathrm{H}_{2} \mathrm{O}(0.2 \mathrm{~mL})$ and hexane $(50 \mathrm{~mL})$ with $250 \mathrm{~W}$ of ultrasound irradiation in an ice

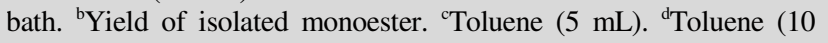
$\mathrm{mL})$.

TABLE-2

\begin{tabular}{|c|c|c|c|}
\hline & $\begin{array}{l}\text { T } \\
\text { OF THE Q } \\
\text { ONOHYDR } \\
\text { AMANTA }\end{array}$ & $\begin{array}{l}2 \\
\text { TY OF W } \\
\text { S OF DIN } \\
\text { ARBOXY }\end{array}$ & \\
\hline Entry & Vol. (mL) & Time $(\mathrm{h})$ & Yield $(\%)^{\mathrm{b}}$ \\
\hline 1 & 0.1 & 2 & 71 \\
\hline 2 & 0.2 & 2 & 88 \\
\hline 3 & 0.3 & 1.2 & 79 \\
\hline 4 & 0.4 & 1.2 & 68 \\
\hline
\end{tabular}

${ }^{\mathrm{a}}$ Dimethyl 1,3-adamantanedicarboxylate $(10 \mathrm{mmol}), p$-TsOH $(0.15$ $\mathrm{mmol})$, hexane $(50 \mathrm{~mL})$ and toluene $(5 \mathrm{~mL})$ with $250 \mathrm{~W}$ of ultrasound irradiation in an ice bath. ${ }^{\text {byeld }}$ of isolated monoester.

of dimethyl 1,3-adamantane dicarboxylate, which could undergo further hydrolysis (entry 3-4). Therefore, $0.2 \mathrm{~mL}$ of $\mathrm{H}_{2} \mathrm{O}$ was used for the remaining monohydrolysis trials.

The effect of the ultrasound irradiation power on the model reaction was examined (Table-3). A blank reaction was conducted using $p$-TsOH as the catalyst and toluene as the co-solvent without ultrasonic irradiation in an ice bath and the monoester was obtained in $68 \%$ yield after $24 \mathrm{~h}$. The reason for the lower yield and longer reaction time of this hydrolysis is thought to be caused by the congregation of the hydrophilic $\mathrm{COOH}$ groups of the resulting monoesters onto the water droplets' surface, which decreased the available reaction area and prohibited the hydrolysis of the remaining diesters. To disturb this congregation and obtain higher yields with shorter reaction times, ultrasonic irradiation was applied to the reaction, which allowed for a rapid work-up (1-2 h). Increasing the irradiation power from $100-250 \mathrm{~W}$ decreased the reaction time from 5 to $1.2 \mathrm{~h}$ and increased the yield from 75 to $88 \%$. The yield did not change further when the power was increased from 250 to $350 \mathrm{~W}$; therefore, $250 \mathrm{~W}$ of ultrasonic irradiation was sufficient to reduce the reaction time.

The reaction and separation temperatures were important factors for the yield and a low reaction temperature were essential for obtaining high yields. When the reaction was carried out at either room temperature or at reflux, the monoester was obtained in a lower yield (58 and $45 \%$, respectively) and the reaction mixture thickened. A considerable amount of the product was observed in the mother liquor by thin-layer chromatography after filtering the precipitate at the reaction temperature. A larger amount of precipitation was obtained when the mixture was filtered at $-20^{\circ} \mathrm{C}$ and the yield was as high as
TABLE-3

EFFECT OF ULTRASOUND IRRADIATION POWER ON THE MONOHYDROLYSIS OF DIMETHYL 1,3-ADAMANTANE DICARBOXYLATE ${ }^{\mathrm{a}}$

\begin{tabular}{cccc}
\hline Entry & Power $(\mathrm{W})$ & Time $(\mathrm{h})$ & ${\text { Yield }(\%)^{\mathrm{b}}}^{\mathrm{b}}$ \\
\hline 1 & 0 & 24 & 68 \\
2 & 100 & 5 & 75 \\
3 & 150 & 5 & 78 \\
4 & 200 & 4 & 82 \\
5 & 250 & 1.2 & 88 \\
6 & 300 & 1 & 88 \\
7 & 350 & 1 & 88 \\
\hline
\end{tabular}

${ }^{a}$ Dimethyl 1,3-adamantanedicarboxylate $(10 \mathrm{mmol}), p$-TsOH $(0.15$ $\mathrm{mmol}), \mathrm{H}_{2} \mathrm{O}(0.2 \mathrm{~mL})$, hexane $(50 \mathrm{~mL})$ and toluene $(5 \mathrm{~mL})$ in an ice

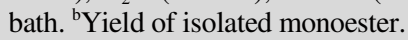

$93 \%$. Therefore, the best yield for $\mathbf{1 a}$ was obtained by filtering the mixture at $-20^{\circ} \mathrm{C}$ after ultrasonic irradiation in an ice bath.

It is interesting that the co-solvent system greatly influenced the reaction (Table-4). Without a co-solvent (entry 1), or when using a nonpolar co-solvent other than toluene, such as $\mathrm{CH}_{2} \mathrm{Cl}_{2}$ and $\mathrm{CCl}_{4}$ (entries 2-3), the solvent system could barely dissolve the catalyst, even when carried out in 1:1 mixture. However, adding polar solvents such as $\mathrm{MeCN}, \mathrm{MeOH}$, acetone, THF and DMSO resulted that monocarboxylic acids could hardly deposit from the mixed solvent system and undergo further hydrolysis to give complicated slurry mixtures of the di- and monocarboxylic acids and starting diesters (entries 4-8). Using toluene as the co-solvent not only dissolved the catalyst, but also deposited most of the resulting monocarboxylic acids from the solvent. This result indicates that toluene is the most effective co-solvent for this monohydrolysis.

TABLE-4

EFFECT OF THE CO-SOLVENTS ON THE MONOHYDROLYSIS OF DIMETHYL 1,3-ADAMANTANE DICARBOXYLATE ${ }^{\mathrm{a}}$

\begin{tabular}{ccc}
\hline Entry & Co-solvent & Yield $(\%)^{\mathrm{b}}$ \\
\hline 1 & None & - \\
2 & $\mathrm{CH}_{2} \mathrm{Cl}_{2}$ & - \\
3 & $\mathrm{CCl}_{4}$ & - \\
4 & $\mathrm{MeCN}$ & 30 \\
5 & $\mathrm{MeOH}$ & 20 \\
6 & Acetone & 22 \\
7 & $\mathrm{THF}$ & 34 \\
8 & DMSO & 25 \\
9 & Toluene & 88 \\
\hline
\end{tabular}

${ }^{\mathrm{a}}$ Dimethyl 1,3-adamantanedicarboxylate $(10 \mathrm{mmol}), p$-TsOH $(0.15$ mmol), $\mathrm{H}_{2} \mathrm{O}(0.2 \mathrm{~mL})$, hexane $(50 \mathrm{~mL})$ and co-solvent $(5 \mathrm{~mL})$ with $250 \mathrm{~W}$ of ultrasound irradiation in an ice bath for $1.2 \mathrm{~h}$. ${ }^{\text {b}}$ Yield of isolated monoester.

To establish the generality of $p$-TsOH catalyzed selective monohydrolysis with ultrasonic irradiation, other polyhedral diesters, such as cubane and homocubane, were used for the synthesis of methyl, ethyl and n-propyl monoesters. These monohydrolyzes were carried out using the optimized conditions previously described. The corresponding monoesters, 2 and $\mathbf{3}$, were formed in excellent yields (78-95 \%) by cooling the mixture to $-20{ }^{\circ} \mathrm{C}$ after a $250 \mathrm{~W}$ ultrasonic irradiation for $1-2 \mathrm{~h}$ in an ice bath using a hexane $(50 \mathrm{~mL})$ and toluene $(5 \mathrm{~mL})$ co-solvent system. The results are summarized in Table-5. All of the monoesters obtained in this way showed satisfactory 


\begin{tabular}{cccc}
\multicolumn{5}{c}{ TABLE-5 } \\
MONOHYDROLYSIS OF POLYHEDRAL \\
DIESTERS CATALYZED BY $p$-TsOH ${ }^{\mathrm{a}}$ \\
\hline 1.
\end{tabular}

${ }^{\text {a Substrate }}(10 \mathrm{mmol}), p$ - TsOH $(0.15 \mathrm{mmol}), \mathrm{H}_{2} \mathrm{O}(0.2 \mathrm{~mL})$, hexane $(50$ $\mathrm{mL}$ ) and toluene $(5 \mathrm{~mL})$, with $250 \mathrm{~W}$ of ultrasound irradiation in an ice

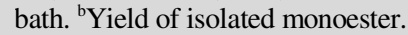

${ }^{1} \mathrm{H}$ and ${ }^{13} \mathrm{C}$ NMR as well as mass spectra, with no peaks from impurities.

Inspecting these results, this method gave as much yield of 2a as the conventional Tsanaktsidis' method ${ }^{8}$ but with a much shorter reaction time and simpler isolation and purification. As expected, steric effects and higher solubility resulted in higher monoester yields for $\mathbf{2}$ than $\mathbf{3}$, while $\mathbf{1}$ was the lowest. As the ester group increased in size, the yields decreased (Me $>$ Et $>n$-Pr). No precipitate formed when the ester group included an isopropyl or $n$-butyl.

\section{Conclusion}

$p$ - $\mathrm{TsOH}$ has been proved to be an excellent catalyst for the selective monohydrolysis of 1,3-adamantane dicarboxylate diesters to form monoesters in a co-solvent under ultrasonic irradiation. The primary parameters that affected the reaction yield were investigated and optimized. Other polyhedral diesters were also successfully monohydrolyzed to their corresponding monoesters using this method. These results show that this method was quite straightforward and clean compared to the classical methods and had the advantages of shorter reaction times and a simpler separation procedure. This work will not only lead to a practical synthetic method for asymmetric diesters with rigid molecular structures, but it also provides a new approach to acid-catalyzed selective monohydrolysis.

\section{ACKNOWLEDGEMENTS}

This work was financially supported by the National Natural Sciences Foundation (No. 20872009) and Natural Sciences Foundation of Beijing (No. 200710005002).

\section{REFERENCES}

1. H. Iding, B. Wirz and R.R. Sarmiento, Tetrahedron: Asymm., 14, 1541 (2003).

2. S. Niwayama and H. Cho, Chem. Pharm. Bull., 57, 508 (2009).

3. S. Niwayama, H. Cho, M. Zabet-Moghaddam and B.R. Whittlesey, J. Org. Chem., 75, 3775 (2010).

4. S. Niwayama, H. Wang, Y. Hiraga and J.C. Clayton, Tetrahedron Lett., 48, 8508 (2007).

5. S. Niwayama, J. Org. Chem., 65, 5834 (2000).

6. A. Hilgeroth and U. Baumeister, Chem. Eur. J., 7, 4599 (2001).

7. T. Carell, E.A. Wintner, A. Bashir-Hashemi and J. Rebek, Angew. Chem., 33, 2059 (1994).

8. E.W. Della and J. Tsanaktsidis, Aust. J. Chem., 39, 2061 (1986).

9. R.M. Moriarty, J.S. Khosrowshahi, R.S. Miller, J. Flippen-Andersen and R. Gilardi, J. Am. Chem. Soc., 111, 8943 (1989).

10. S. Iimura, K. Manabe and S. Kobayashi, Org. Lett., 5, 101 (2003).

11. M.E. Donaldson, V.L. Llopis Mestre, D. Vinci, C.L. Liotta and C.A. Eckert, Ind. Eng. Chem. Res., 48, 2542 (2009).

12. K. Tanaka, K. Yoshida, C. Sasaki and Y.T. Osano, J. Org. Chem., 67, 3131 (2002).

13. T.I. Ho, J.H. Ho and J.Y. Wu, J. Am. Chem. Soc., 122, 8575 (2000).

14. A. Kamal, S.F. Adil and M. Arifuddin, Ultrason. Sonochem., 12, 429 (2005).

15. G. Cravotto, G. Palmisano, S. Tollari, G.M. Nano and A. Penoni, Ultrason. Sonochem., 12, 91 (2005).

16. M.M. Mojtahedi, M.S. Abaee, V. Hamidi and A. Zolfaghari, Ultrason. Sonochem., 14, 596 (2007).

17. M.L. Bagal and V.I. Lantovoev, Z. Organ. Khim., 9, 291 (1973).

18. P.E. Eaton, Y.S. Xiong and J.P. Zhou, J. Org. Chem., 57, 4277 (1992). 